\title{
Front Matter: Volume 11838
}

, "Front Matter: Volume 11838," Proc. SPIE 11838, Hard X-Ray, Gamma-Ray, and Neutron Detector Physics XXIII, 1183801 (16 September 2021); doi:

$10.1117 / 12.2606440$

SPIE Event: SPIE Optical Engineering + Applications, 2021, San Diego, California, SPIE. United States 


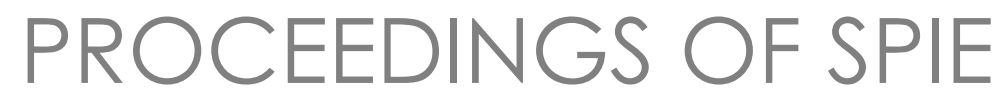

\title{
Hard X-Ray, Gamma-Ray, and Neutron Detector Physics XXIII
}

\author{
Nerine J. Cherepy \\ Michael Fiederle \\ Ralph B. James \\ Editors
}

1-5 August 2021

San Diego, California, United States

Sponsored and Published by

SPIE 
The papers in this volume were part of the technical conference cited on the cover and title page. Papers were selected and subject to review by the editors and conference program committee. Some conference presentations may not be available for publication. Additional papers and presentation recordings may be available online in the SPIE Digital Library at SPIEDigitalLibrary.org.

The papers reflect the work and thoughts of the authors and are published herein as submitted. The publisher is not responsible for the validity of the information or for any outcomes resulting from reliance thereon.

Please use the following format to cite material from these proceedings:

Author(s), "Title of Paper," in Hard X-Ray, Gamma-Ray, and Neutron Detector Physics XXIII, edited by Nerine J. Cherepy, Michael Fiederle, Ralph B. James, Proc. of SPIE 1 1838, Seven-digit Article CID Number (DD/MM/YYYY); (DOI URL).

ISSN: 0277-786X

ISSN: 1996-756X (electronic)

ISBN: 9781510645141

ISBN: 9781510645158 (electronic)

Published by

SPIE

P.O. Box 10, Bellingham, Washington 98227-0010 USA

Telephone +1 3606763290 (Pacific Time)

SPIE.org

Copyright (C) 2021 Society of Photo-Optical Instrumentation Engineers (SPIE).

Copying of material in this book for internal or personal use, or for the internal or personal use of specific clients, beyond the fair use provisions granted by the U.S. Copyright Law is authorized by SPIE subject to payment of fees. To obtain permission to use and share articles in this volume, visit Copyright Clearance Center at copyright.com. Other copying for republication, resale, advertising or promotion, or any form of systematic or multiple reproduction of any material in this book is prohibited except with permission in writing from the publisher.

Printed in the United States of America by Curran Associates, Inc., under license from SPIE.

Publication of record for individual papers is online in the SPIE Digital Library.

\section{SPIE. DIGITAL}

Paper Numbering: A unique citation identifier (CID) number is assigned to each article in the Proceedings of SPIE at the time of publication. Utilization of CIDs allows articles to be fully citable as soon as they are published online, and connects the same identifier to all online and print versions of the publication. SPIE uses a seven-digit CID article numbering system structured as follows:

- The first five digits correspond to the SPIE volume number.

- The last two digits indicate publication order within the volume using a Base 36 numbering system employing both numerals and letters. These two-number sets start with 00, 01, 02, 03, 04, 05, 06, 07, 08, 09, 0A, OB ... 0Z, followed by 10-1Z, 20-2Z, etc. The CID Number appears on each page of the manuscript. 


\section{Contents}

CZT

1183805 Evaluation and benchmarking of a commercial cadmium zinc telluride (CZT) gamma imaging camera [1 1838-4]

1183806 A CdZnTeSe gamma spectrometer trained by deep convolutional neural network for radioisotope identification [11838-5]

\section{SCINTILLATOR DETECTORS}

1183807 Ultra-compact high detection efficiency detectors with high-density scintillators on SiPM [11838-7]

$11838 \mathrm{OA}$ Evaluation of novel bismuth-loaded plastic arrays for fast neutron radiography [1 1838-10]

PEROVSKITES

$11838 \mathrm{OB} \quad$ Perovskite detectors for $x$-ray imaging and gamma spectroscopy: overview and current state-of-the-art (Invited Paper) [1 1838-11]

INORGANIC SCINTILLATORS

11838 OG Bright infrared scintillators for gamma spectroscopy (Invited Paper) [1 1838-16]

11838 Ol Progress on inorganic scintillators for future HEP experiments (Invited Paper) [1 1838-18]

\section{RADIOGRAPHY AND CT}

11838 OK Improved $x$-ray CT feature identification with complementary fast neutron CT (Invited Paper) [11838-20]

$11838 \mathrm{OL} \quad$ Fast neutron computed tomography of multi-material complex objects [11838-21]

11838 ON A large area detector with indirect conversion, charge integration and photon counting operation [1 1838-23]

11838 OP Lens-coupled MeV x-radiography and CT with transparent ceramic GLO scintillators [1 1838-25] 
ORGANIC SCINTILLATORS

11838 OR Nano-segmented optical fibers containing molecular organic glass scintillator for fast neutron imaging (Invited Paper) [1 1838-27]

11838 OS Organic liquid and nanocomposite scintillators for gamma spectroscopic detections [11838-28]

INSTRUMENTATION

11838 OU Novel technologies for Linac-based radiotherapy (Invited Paper) [11838-30]

11838 OV Analytic von Hamos geometry optimization and calibration [1 1838-31]

\section{ALTERNATIVE SEMICONDUCTORS}

1183812 The electron detection performance of the "Icarus" hCMOS imaging sensor [1 1838-38]

1183813 Simplification of imaging system for estimating changes in image contrast due to different weighting of $\mathrm{x}$-ray energy [11838-39]

1183814 Direct current response of a thin sCCVD diamond detector under increased applied field to 14.1 MeV neutrons [1 1838-40]

1183815 Observation of minority carrier traps using C-DLTS in AU/SiO $2 / \mathbf{n}-\mathbf{4 H}$-SiC vertical MOS capacitor [11838-41]

$1183816 \quad$ High-resolution $4 \mathrm{H}-\mathrm{SiC}$ Schottky barrier radiation detectors on $\mathbf{2 5 0} \boldsymbol{\mu m}$ epitaxial layers for harsh environment applications [1 1838-42]

POSTER SESSION

1183817 High radiation resistant crystals for $\mathrm{x}$-ray and $\mathrm{Y}$-radiation detectors [11838-43]

1183819 Thermodynamics and crystal growth of $\mathrm{Cd}_{1-\mathrm{x}-\mathrm{y}} \mathrm{Mn}_{\mathrm{x}} \mathrm{Zn}_{\mathrm{y}} \mathrm{Te}(\mathrm{x}=\mathbf{0 . 1 0}, \mathbf{0 . 2 0}, \mathrm{y}=\mathbf{0 . 1 5})[11838-45]$

11838 1B Radiation resistance of $\mathrm{Hg}_{3} \ln _{2} \mathrm{Te} \mathrm{e}_{6}$ near-infrared photodiodes [1 1838-47]

11838 1C 3D expression with rendering method for photon counting multi energy $x$-ray CT [1 1838-48]

11838 IE Demonstration of polarization behavior of TIBr X-ray imager with silver electrodes [1 1838-50]

iv 